\title{
ESOPHAGEAL MANOMETRY AND VECTORCARDIOGRAPHY STUDY OF ASYMPTOMATIC PATIENTS WITH CHAGAS' DISEASE
}

Joaquim Prado P. MORAES.FILHO (1), Thelma A. Bombonatti P. P. MORAES (2), Valter N. FELIX (3), Antonio Carlos PEREIRA-BARReto (4) \& Agostinho BeTTARELLO (5)

\begin{abstract}
SUMMARY
The indeterminate form of Chagas' disease is characterized by positive serology for the disease in the absence of clinical findings and in the presence of both normal esophagogram and electrocardiogram. When more sensitive methods were used, abnormalities have been described either in the esophagus or in the heart.

The authors have studied simultaneously the esophagus and the heart in the same subjects. In thirteen adults with diagnosis of indeterminate form and nine adult controls, the esophageal manometry both in basal conditions and after stimulus (bethanecol) and vectorcardiogram were performed.

In the control group none of the subjects presented concomitant esophageal and cardiac alterations while in the chagasic group $92.3 \%$ of the patients presented results simultaneously altered.

It is concluded that the studied patients showed indications of parasympathetic denervation manifested by simultaneously esophageal and heart alterations.
\end{abstract}

KEY WORDS: Chagas' disease-indeterminate form

\section{INTRODUCTION}

Chagas' disease is a common disease in South America affecting, only in Brazil, 5 to 10 million of persons ${ }^{5}$. Produced by Trypanosoma cruzi, the infection damages the parasympathetic ganglia ${ }^{9,} 10$.

In the indeterminate form of the disease the patients present positive serologic or xenodiagnostic tests in the absence of clinical manifestations. Characteristically, the radiological study of the heart, of the digestive tube and the electrocardiogram reveal normal results ${ }^{13}$. ${ }^{16}$.
However, procedures which enable a more accurate analysis have showed that cardiac $^{1.3}$ 4. 6. 11 and/or digestive changes ${ }^{8.14 .15}$ may be demonstrated. Nevertheless these manifestations have not been observed simultaneously in the same individuals, a finding which difficults a whole evaluation of the disease.

The objective of the present paper was to study the esophagus and heart of patients with the indeterminate form of Chagas' disease, in

(1) Associate Professor. Department of Gastroenterology. University of Sâo Paulo School of Medicine.

(2) Assistant Professor of Public Health. University of Sáo Paulo Public Health School.

(3) Assistant Professor Surgery. Department of Gastroenterology. University of Sáo Paulo School of Medicine.

(4) Associate Professor. Heart Institute. University of Sāo Paulo School of Medicine.

(5) Professor of Gastroenterology. Department of Gastroenterology. University of Săo Paulo School of Medicine.

Address for correspondence: J. Prado P. Moraes Filho, MD. FACP. Dep de Gastroenterologia Hospital das Clínicas da USP Sala 6089. Av. Dr. Enéas de Carvalho Aguiar, 255. CEP 05403. São Paulo, SP. Brasil. 
MORAES-FILHO, J. P P.: MORAES. T. A. B. P. P ; FELIX, V. N : PEREIRA-BARRETO, A. C. \& BETTARELLO, A. - Esophageal manometry and vectorcardiography study of asymptomatic patients with Chagas' disease. Rev. Inst. Med. trop. Sảo Paulo, 30 (6): 406 410, 1988

an attempt to characterize simultaneous changes in the same subjects.

\section{PATIENTS AND METHODS}

Twenty two adult subjects were studied. They presented no complaints and normal physical examination. The electrocardiogram, chest $\mathrm{X}$-rays and barium meal $\mathrm{X}$-rays did not show any changes. They were classified into two groups, according to the results of serologic tests for Chagas' disease (indirect immunofluorescence and fixation of the complement reaction):

1. Control group. Composed by nine women from the Outpatient Division of the Department of Gastroenterology, ages from 18 to 48 (mean 32.3 years), with negative serologic tests.

2. Chagas' disease group. Composed by thirteen patients from the Hospital das Clínicas Blood Bank where they were registered as blood donators and had positive serologic reactions. Eight men and 5 women, ages from 21 to 58 (mean 36.8 years).

Informed consent was obtained. The study was approved by the Department Ethics Committee.

\section{Esophageal manometry.}

Determination of basal lower esophageal sphincter (1.e.s.) pressure was carried out during station pull-through with a standard three channel continuous perfusion catheter. Perfusion at $0.6 \mathrm{ml} / \mathrm{min}$ was done with a hydraulic infusion system (Univ. S. Paulo, Brazil). Intraluminal pressure was transmitted from the catheter assembly to external transducers and their output recorded on a multichannel recording system (Hewlett-Packard, U.S.A.). The presence and amplitude of the peristaltic waves in the body of the esophagus were also studied.

A. Study under basal conditions. The motor recording was initiated with the study of the 1.e.s. considering the amplitude of pressure. The sphincteral openings were also studied, being considered complete when the deflection of the registrator pen reached the baseline.

The manometric patterns, in the body of the esophagus, were analysed as follows: a) presence of aperistaltic waves; b) presence of spontaneous waves; c) morphological aspect of the waves, being considered normal those with monophasic aspect, and iterative those with bi or polyphasic aspect.

B. Study under cholinergic stimulation. After the esophageal study under basal conditions. bethanecol hydrochloride (Urecholine, Merck Sharp \& Dohme) $0.08 \mathrm{mg} / \mathrm{kg}$ body weight was administered subcutaneously. The recording of motor activity under stimulation was initiated approximately five minutes after the drug admi nistration, following the same procedures descri bed for the manometric recording under basal conditions.

C. Classification of esophageal motility alterations. The esophageal motor changes roth basal and after stimulation were classified in "grades", as follows:

0 - absence of any motor disturbance in the 1.e.s. (amplitude, openings) and in the bo dy of the esophagus (peristalsis, waves);

I - one alteration observed either in the lower esophageal sphincter or in the body of the esophagus:

II - two motor alterations observed simulta neously in the 1.e.s, in the body of the esophagus, or both;

III - three or more motility alterations obser ved simultaneously in the 1.e.s., in the bo dy of the esophagus, or both.

\section{Cardiac study}

The vectorcardiographic method using the Frank system of corrected leads ${ }^{7}$ was used in three plans: horizontal, sagital and frontal. Ma jor importance was attributed to the curve of ventricular depolarization, when rotation, dura tion and orientation of terminal maximum vec tor were evaluated in relation to each plan. The curve of ventricular repolarization in relation to each plan was also analysed according to the orientation, magnitude and morphology of the maximum vector. The loop corresponding to atrial depolarization was disregarded. 
MORAES-FILHO, J. P. P.: MORAES, T. A. B P. P.: FFLIX.V. N. PEREIRA-BARRFTO. A. C. \& BETTARFLLO. A. - Esophageal manometry and vectorcardiography study of asymptomatic patients with Chagas disease Rev. Inst. Med. trop. Sào Paulo. 30 (6): 406410 . 1988

\section{Statistical study}

Student "t" test was used to compare the amplitude of 1.e.s., between the control group and the group with Chagas' disease before and after cholinergic stimulation. and the $\mathrm{X}^{2}$ test to compare the results of the control group and the group with Chagas disease regarding ope nings of the 1.e.s. and the deglutition waves.

\section{RESULTS}

\section{Control Group}

Esophagus. The results of the manometric study are presented in table 1 . In six subjects the esophageal alterations were graded as zero (numbers $2,3,4,5,7,8$. Three presented esopha geal changes grade I (numbers $1,6,9$ ).

TABLE 1

Results of manometry in the rontrol group and Chatas disfase sroulp

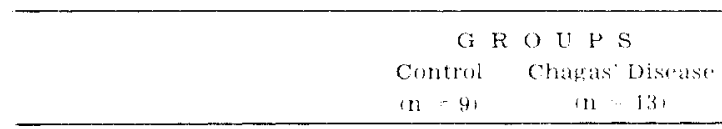

Basal conditions

Lower esophageal sphineter Pressure Ineomplete openiness

Body of esophayus Aperistalsis Spontaneous waves Iterative waves

$\begin{array}{cc}23.33 \pm 3.61 & 34.76 \cdot 1.86 \\ 1 & 3 \\ 0 & 0 \\ 1 & 0 \\ 0 & 5\end{array}$

Cholinergie stimulation

Lowor esophageal sphincter Pressure* Incomplete openings

Body of esophagus Aperistalsis Spontaneous waves Iterative waves $23.67: 3.16 \quad 55.23 \div 14.52$ 10

Data are moat 5 SE romH Or, n :- number of cases studied

Heart. Three of nine individuals presented abnormal results on vectorcardiogram: proemi nerit anterior QRS and or septal fibrosis and or left anterior hemi-block and/or septal fibrosis (numbers, $3,7,8$ ). Six individuals presented nor mal results (numbers $1,2,4,5,6,9$ ).

\section{Chagas' Disease Group}

Esophagus. The results of the manometric study are presented in table 1. Esophageal chan ges were observed in all the patients: two with grade I (numbers 4,6 ) and 11 with grades II (num bers $3,9,12$ ) and III numbers $1,2,5,7,8,10$. 11. 13 ).

Heart. Twelve patients presented abnomal vectorcardiographic results: ST T change ber's 5.10 : ST T change + final delay of conduc tion (numbers 2, 12); left ventricular hypertrophy $(1,3,4,9)$ : final delay of conduction $(7,8)$ : final delay of conduction + left ventricular hypertro phy $(11,13)$. Vectorcardiographic examination was not done in one patient (number 6 ).

\section{Comparison between groups}

\section{Esophagus}

A. Basal conditions. Statistically significant differences $(p<0.05$ ) were observed between con trol and Chagas disease group in the following parameters: amplitude of 1.e.s. presence of itera tive waves, and presence of spontaneous waves. There was no statistical difference between both groups $(\mathrm{p}>0.05)$, as to the presence of incom plete openings of the l.e.s.

B. Cholinergic stimulation. Statistically significant differences $(\mathrm{p}<0.05$ ) were observed between control and Chagas' disease group in the following parameters: amplitude of 1.e.s. presence of iterative waves and presence of spon taneous waves. There was no statistically signifi cant difference between the two groups ip $\quad 0.05$ regarding the presence of incomplete openings of the 1.e.s.

\section{Heart}

As far as vectorcardiograpme changes were concerned, the chagasic group showed a greater number of alterations than the control group $(\mathrm{p}<0.05)$

\section{Esophagus theart}

In the control group there was no concomi tant occurrence of esophageal and cardiac chan ges; in the Chagas' disease group, 12 patients showed alterations in both organs.

\section{DISCUSSION}

Previous investigations have shown single involvement either of esophagus ${ }^{8.14} \cdot 15$ or of the 
MORAES-FILHO J. P. P.: MORAES. T. A. B. P. P.: FELIX. V. N : PEREIRA-BARRETO. A. C. \& BETTARELLO A. - Esophageal manometry and vectorcardiography study of asymptomatic patients with Chagas' disease. Rev. Inst. Med. trop. Sào Paulo, 30 (6): 406410.1988

heart ${ }^{3.4,6.11}$ in the indeterminate form of Chagas' disease. In the present study, it has been showed that such involvement occurs concomitantly in both organs.

Taking in consideration studies of esopha geal motility, it is difficult to stablish a compa rison with previous results, since in the present investigation we evaluated the esophageal alte rations grading the motor disturbances, whereas this assessment has not been made in previous works. MORAES-FILHO ${ }^{15}$ showed that 1.e.s. pressure was significantly higher in $75 \%$ of the patients with indeterminate form of Chagas' di sease. Such authors however did not evaluate the behaviour of the body of the organ: this evaluation could have also indicated the presence of motor disorders as demonstrated here.

The vectorcardiographic results showed alterations in 12 of our patients $(92.3 \%)$, a finding which is similar to those of MADY et al ${ }^{12}$ and BARRETO et al. ${ }^{4}$ who showed changes, respectively in $88.3 \%$ and $66.6 \%$ of the cases. The vectorcardiographic alterations may be related to the damage of the parasympathetic ganglia ${ }^{2}$ whose severity can be lower or higher according to the different evolutionary stages of the disease.

The finding of vectorcardiographic changes under basal conditions indicated that there was no need of cholinergic stimulation in our patients for the detection of cardiac abnormalities. Such fact suggests that at this stage of the disease, the heart is more susceptible to the damage by $T$ cruzi than the esophagus, since in the latter organ some of the motor changes could only be observed under cholinergic stimulation.

The abnormalities described in the present study could not be detected either clinically or through the routine studies. These observations are in accordance with the findings of KOBERLE \& NADOR ${ }^{10}$ who found that dilatation of the esophagus, with the development of the megaesophagus occurs only when at least $90 \%$ of the cells of the myoenteric plexuses are destroyed. The finding of aiterations in different stages both in the esophagus and in the heart suggests that these organs were injured at different grades by T. cruzi
Although the denomination "indeterminate form" has been largely used, we consider that its significance has not been fully understood. What is really indeterminate is the future of the patients in relation to the manifestation of the di sease, either cardiac, esophagic or both, among others. Regarding the clinical aspects, the heart and the esophagus are both affected: such manifestations will basically depend on the degree of neuronal destruction and functional over load to which the different organs are subjected, as well as on other factors not yet clearly defined.

\section{RESUMO}

\section{Manometria esofágica e estudo vetorcardiográ- fico em pacientes assintomáticos portadores de Doença de Chagas}

A forma indeterminada da Doença de Cha gas é caracterizada por sorologia positiva com ausência de manifestaçōes clínicas, na presença de resultados normais aos exames radiológico do tubo digestivo e eletrocardiográfico.

No presente trabalho, os autores estudam simultaneamente o esôfago e o coração, nos mes mos indivíduos. Treze adultos com diagnóstico de forma indeterminada da Doença de Chagas e nove adultos controles foram submetidos ao exame vetorcardiográfico e à manometria esofágica em condições basais e sob estímulo com cloridrato de betanecol $(0,08 \mathrm{mg} / \mathrm{kg} \mathrm{p.c.)}$. No grupo controle nenhum dos individuos apresentou concomitância de alteraçōes esofágicas e cardía cas, enquanto no grupo chagásico $92,3 \%$ dos pa cientes apresentaram exames concomitantemente alterados.

Concluem que os pacientes estudados apresentam evidências de desnervação parassimpática manifestada por alteraçoes simultâneas eso fágicas e cardíacas.

\section{ACKNOWLEDGEMENTS}

The authors wish to thank to Mrs. Paula Strassman for the statistical analysis and Ms. M. Cecilia P. Pinheiro for the bibliographical as sistance. 
MORAES-FILHO. J F P : MORAES. T A B. P. P : FELIX. V. N : PEREIRA-BARRETO, A C \& BETTARELLO. A. - Esophageal manometry and vectorcardiography study of asymptomatic patients with Chagas' disease Rev. Inst. Med. trop. Sāo Paulo, 30 (6): 406410.1988

\section{REFERENCES}

1. ACQUATELla, H : SCHILleR, N, B : PUIGBO, J. J GIORDANO, H : STIAREZ, J A : CASAL. H : ARREAZA N. VALECITLOS, R. \& HIRSCHNAUT. E - M mode and two dimensional echocardiography in chronic Chagas' di sease. A clinical and pathologic study. Circulation. 62 787-799. 1980

2. ALMEIDA. H O.: TEIXEIRA, V P. A. ARAUIO, W F \& GOBBI, H. - Alteraçoes do sistema nervoso autonomo intracardiaco em chagásicos com e sem "megas" Rev. goiana Med., 29: 147156,1983

3 ALMEIDA J W R SHIKANAI YASUDA M A AMATO NETO. V: CASTILHO. E. A. \& BARRETO. A. C P. Estudo na forma indeterminada da doenca de Chagas através da eletrocardiografia dinámica Rev. Inst. Med trop. S. Paulo, 24: 222 228, 1982

4. BARRETO, A. C. P.: DECOURT. L. V.: IANNI. B. M.: VIA NNA, C. B : ARTEAGA FERNANDEZ.E MADY C BE LLOTTI. G. \& PILEGGI, F. J. C - Comprometimento do coração na forma indeterminada da doença de Chagas Estudo comparativo dos resultados obtidos por metodos náo invasivos. Arch. bras. Cardiol., 43 (supl . 124 1984

5. BOMBONATTI T A \& MORAES FILHO J P P O enigma de Chagas. Rev. bras. Med.. 40: 113116.1983

6. BOMBONATTI T A : MORAES FILHO J P P : FELIX V. N : MAGALHÄES, S. C. M.: VIDOTTI, M H., MOFFA. P. G : BARRETO, A C P. BELOTTI G : PILFGGI. F \& BETTARELLO A - Forma indeterminada da doença de Chagas. Comprometimento cardiaco e esofágico. Arch. bras. Cardiol., 43 (supl.) 115. 1984

7. FRANK, E. - An accurate clinically practical system for spacial vectoreardiography Circulation, 13:737 749.1956.
8. GODOY R A - Estudo da esofagopatia chagásica cró nica por meio do metodo eletromanometrico a da prova da metacolina em pacientes com e sem dilataçào de esófa go. Rev.goiana Med., 18: 1731972

9. KOBERLE. F. - Cardiopatia chagásica. Hospital (Rie de J.J, 53: 311346,1958

10 KÖBERLE, F \& NADOR. E. -. Etjologia p patogenia do megaesofago no Brasil. Rev. paul. Med., 47: 643.661 1955

11. MADY, C. BARRETO. A. C P. IANNI B M: LOPES E. A. \& PILEGGI.F - - Right ventricular endamyorardial biopsy in undetermined form of Chagas' disease Angio $\log \mathbf{y}, 35: 755759,: 984$

12. MADY C : BARRETO. A. C. P : MOFFA. P. J.: IANNI B. M. ARTEAGA FERNANDEZ, E.; BELOTTI, G \& PI LEGGI, F. - O vetorradiograma na forma indeterminada da doenca de Chagas Arch. bras. Cardiol. 44: 8385,1985

13. MADY C \& DECOURT, L V - A forma indeterminada da doença de Chagas. Arch. bras. Cardiol., 36: 143145 1981

14. MORAES FILHO. J.P. P. - Açáo da pentagastrina no esfincter inferior do esófago de pacientes com megaesó fago chagasico. Rev. goiana Med., 31: 95 123. 1985

15 MORAES FILHO J P P : KOHATSU O S \& BETTA RELLO, A - Pressāo basal do esfincter inferior do esófa go na doenca de Chagas: megaesofago e forma indeter munada. Rev. Ass. med hras, 32:51 53,1986

VALIDADE da conceito de forma indeterminada de doen ca de Chagas. Rev. Soc bras. Med. trop., 18: 46. 1985

Recebido para publicaça em 2241988 